\title{
Implikasi Keberadaan Agens Hayati Neochetina eichhorniae Warner (Coleoptera: Curculionidae) terhadap Eceng Gondok
}

\author{
SAPDI", DAMAYANTI BUCHORI ${ }^{2)}$, UTOMO KARTOSUWONDO ${ }^{2)}$, SUKISMAN \\ TJIROSEMITO ${ }^{3)}$, BANDUNG SAHARI ${ }^{4)}$
}

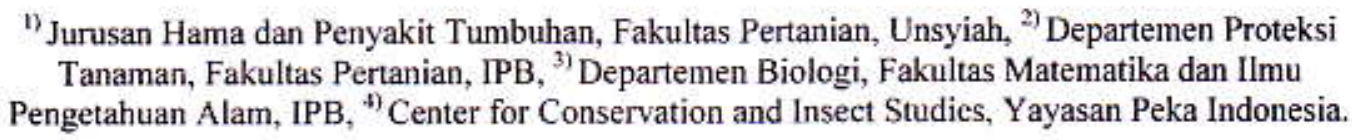

(diterima Mei 2006, disetujui November 2006)

\begin{abstract}
Implication of The Biocontrol Agent, Neochetina eichhorniae Existence on Waterhyacinth. The effectiveness of Neochetina eichhorniae as a biocontrol agent of waterhyacinth was evaluated in West Java and DKI Jakarta. The objective of this research was to study the implication of the existence of $N$. eichhorniae on waterhyacinth. Research was conducted in several freshwater ecosystem infested by waterhyacinth and $N$. eichhorniae, including Cibinong and Lido lakes (Bogor District), Muara Angke Sanctuary (North Jakarta), and Citarum Hulu river (Purwakarta District), conducted during April to August 2004. The impact of $N$. eichhorniae on waterhyacinth was evaluated by leaf damage intensity and growth parameter of the plant. Results showed that there was no correlation between waterhyacinth and the occurrence of the $N$. eichhorniae. The population of $N$. eichhorniae adults was significantly low in any locations studied. Thus, the existence of the biocontrol agent can not result in decreasing of waterhyacinth population.
\end{abstract}

KEY WORDS: Neochetina eichhorniae, biocontrol, waterhyacinth.

\section{PENDAHULUAN}

Eceng gondok, Eichhornia crassipes (Mart.) Solms. (Pontederiaceae) merupakan salah satu spesies tumbuhan yang dikenal sangat invasif dan telah menyebar ke seluruh dunia. Sifat invasif eceng gondok berkaitan dengan tingginya daya adaptasi dan laju reproduksi tumbuhan ini sehingga hampir selalu memenangkan kompetisi dengan spesies tumbuhan lain
(Gopal \& Sharma 1981; Center et al. 2002). Eceng gondok dapat hidup di daerah tropis dan subtropis (Gopal \& Sharma 1981), terdistribusi mulai dari latitude $40^{\circ}$ Lintang Utara hingga $40^{\circ}$ Lintang Selatan (Center et al. 2002).

Di Indonesia, keberadaan spesies invasif eceng gondok pada saat ini cukup memprihatinkan karena sebagian besar ekosistem air tawar di Indonesia telah terinfestasi oleh tumbuhan invasif ini. Tjitrosoedirdjo dan Wijaya 
(1991) melaporkan bahwa perairan terbuka yang telah terinfestasi oleh eceng gondok meliputi hampir seluruh wilayah Indonesia, mulai dari Sumatera, Jawa, Kalimantan dan Irian Jaya.

Berbagai upaya telah dilakukan untuk mengatasi invasi eceng gondok di Indonesia. Salah satu teknik yang dikembangkan adalah pengendalian secara biologi, yaitu dengan memanfaatkan musuh alami gulma tersebut berupa serangga herbivor. Neochetina eichhorniae Warner (Coleoptera: Curculionidae) merupakan salah satu serangga herbivor yang dimanfaatkan sebagai agens pengendalian hayati eceng gondok. Agens hayati ini diintroduksi dari Florida, USA pada tahun 1975 dan pertama kali dilepaskan di Danau Cibinong, Bogor pada tahun 1979 (Widayanti et al. 1999). Introduksi dan pelepasan agens hayati tersebut diharapkan dapat menekan perkembangan populasi eceng gondok.

Tidak seperti keberhasilan yang dicapai di danau Victoria, Uganda (Ogwang 2001) dan di Amerika Serikat (Center et al. 1999), pelepasan $N$. eichhorniae untuk mengendalikan eceng gondok di Indonesia nampaknya tidak memberikan hasil yang memuaskan. Menurut Widayanti et al. (1999), meskipun $N$. eichhorniae diperkirakan telah menyebar secara alami di seluruh Pulau Jawa, nampaknya keberadaan agens hayati ini belum mampu menekan populasi eceng gondok. Namun demikian, sejauh ini evaluasi terhadap aspek keefektifan $N$. eichhorniae dalam mengendalikan populasi eceng gondok di lapangan belum banyak dilakukan.

Bertitik tolak pada uraian di atas, evaluasi secara terencana terhadap keefektifan $N$. eichhorniae dalam mengendalikan populasi eceng gondok perlu dilakukan. Secara umum penelitian ini bertujuan untuk mempelajari implikasi keberadaan $N$, eichhorniae terhadap eceng gondok. Secara spesifik, penelitian ini bertujuan untuk mengevaluasi intensitas kerusakan eceng gondok yang ditimbulkan oleh $N$. eichhorniae, serta bagaimana dampak keberadaan agens hayati ini terhadap parameter pertumbuhan eceng gondok.

\section{BAHAN DAN METODE}

\section{Tempat dan Waktu Penelitian}

Penelitian ini dilakukan pada beberapa ekosistem perairan di Jawa Barat dan DKI Jakarta. Lokasi ditentukan berdasarkan purposive sampling method, yaitu meliputi ekosistem perairan yang terinfestasi eceng gondok dan $N$. eichhorniae. Dari hasil survey pendahuluan maka ditetapkan empat lokasi penelitian, yaitu: Danau Cibinong $\left(06,469^{\circ}\right.$ Lintang Selatan (LS), $106,858^{\circ}$ Bujur Timur (BT) dengan ketinggian 117 meter di atas permukaan laut (mdpl)); Danau Lido $\left(06,736^{\circ} \mathrm{LS}, 106,808^{\circ} \mathrm{BT}\right.$, ketinggian 512 mdpl), Suaka Margasatwa Muara Angke $\left(06,115^{\circ}\right.$ LS, $106,767^{\circ}$ BT, 
ketinggian $28 \mathrm{~m} . \mathrm{dpl}$ ); dan sungai $\mathrm{Ci}$ tarum Hulu, Purwakarta $\left(06,507^{\circ} \mathrm{LS}\right.$, $107,392^{\circ} \mathrm{BT}$, ketinggian $56 \mathrm{mdpl}$ ). Pengambilan sampel berlangsung sejak April sampai Agustus 2004.

\section{Pengambilan Sampel $N$. eichhorniae}

Pengambilan imago N. Eichhorniae dilakukan secara manual dengan tangan (hand picking). Untuk setiap lokasi, pengambilan kumbang tersebut dilakukan pada petak kuadrat berukuran $1 \mathrm{~m}^{2}$, dengan 5 kali ulangan. Jarak antar petak sampel $\pm 10 \mathrm{~m}$. Individu imago yang ditemukan pada setiap petak sampel dihitung dan dicatat jumlahnya. Pengamatan terhadap imago $N$. eichhorniae dilakukan sebulan sekali selama 5 bulan, mulai April hingga Agustus 2004.

\section{Dampak Keberadaan $N$. Eichhorniae terhadap Eceng Gondok}

Evaluasi dampak keberadaan $N$. eichhorniae terhadap eceng gondok dilakukan dengan mengikuti metode seperti yang diuraikan Ochiel et al. (2001). Pengamatan dilakukan terhadap intensitas kerusakan daun dan parameter pertumbuhan eceng gondok (biomassa, jumlah daun per rumpun, dan diameter daun). Intensitas kerusakan daun diukur berdasarkan jumlah bekas ketaman akibat aktivitas makan kumbang tersebut. Jumlah bekas ketaman dihitung pada tiga helai daun termuda yang telah terbuka secara sempurna, dari setiap petak diambil 5 rumpun eceng gondok secara diagonal, kemudian dihitung rataratanya. Selanjutnya, sebanyak 50 bekas ketaman diukur luasnya untuk menentukan rata-rata luas ketaman tersebut. Nilai rata-rata ini selanjutnya dikalikan dengan jumlah bekas ketaman, kemudian dibagi dengan total luas helaian daun. Intensitas kerusakan daun dan parameter pertumbuhan eceng gondok diamati setiap bulan hingga $5 \mathrm{kali}$, bersamaan dengan pengamatan terhadap imago $N$. eichhorniae.

\section{Analisis Data}

Data tentang intensitas kerusakan daun eceng gondok antar lokasi, dianalisis dengan ANOVA satu arah (one-way ANOVA) dan Uji Jarak Berganda Duncan (DMRT) pada selang kepercayaan 95\% untuk melihat signifikansi perbedaannya. Analisis tersebut dilakukan dengan program Statistica for Windows 6.0 .

Untuk melihat tingkat keaktifan $N$. eichhorniae dilakukan analisis korelasi antara jumlah imago kumbang tersebut dengan jumlah bekas ketaman. Sementara itu, untuk melihat seberapa jauh dampak agens hayati tersebut terhadap eceng gondok dilakukan analisis korelasi antara jumlah imago dengan ketiga parameter pertumbuhan eceng gondok. 
HASIL DAN PEMBAHASAN

\section{Hasil}

\section{Intensitas Kerusakan Enceng} Gondok oleh $N$, eichhorniae

Intensitas kerusakan daun eceng gondok oleh $N$. eichhorniae sangat rendah, yaitu rata-rata kurang dari $6 \%$ dan jumlah bekas ketaman maksimum sekitar 200 per helai daun. Intensitas kerusakan daun paling rendah ditemukan di Lido dan berbeda nyata dengan lokasi lainnya $\left(\mathrm{F}_{3,16}=3,882 ; \mathrm{p}=0,0292\right)$. Demikian juga dengan jumlah bekas ketaman di Lido paling rendah dan berbeda nyata dengan lokasi lainnya $\left(F_{3,16}=7,851 ; p=0,002\right)$ (Gambar 1).
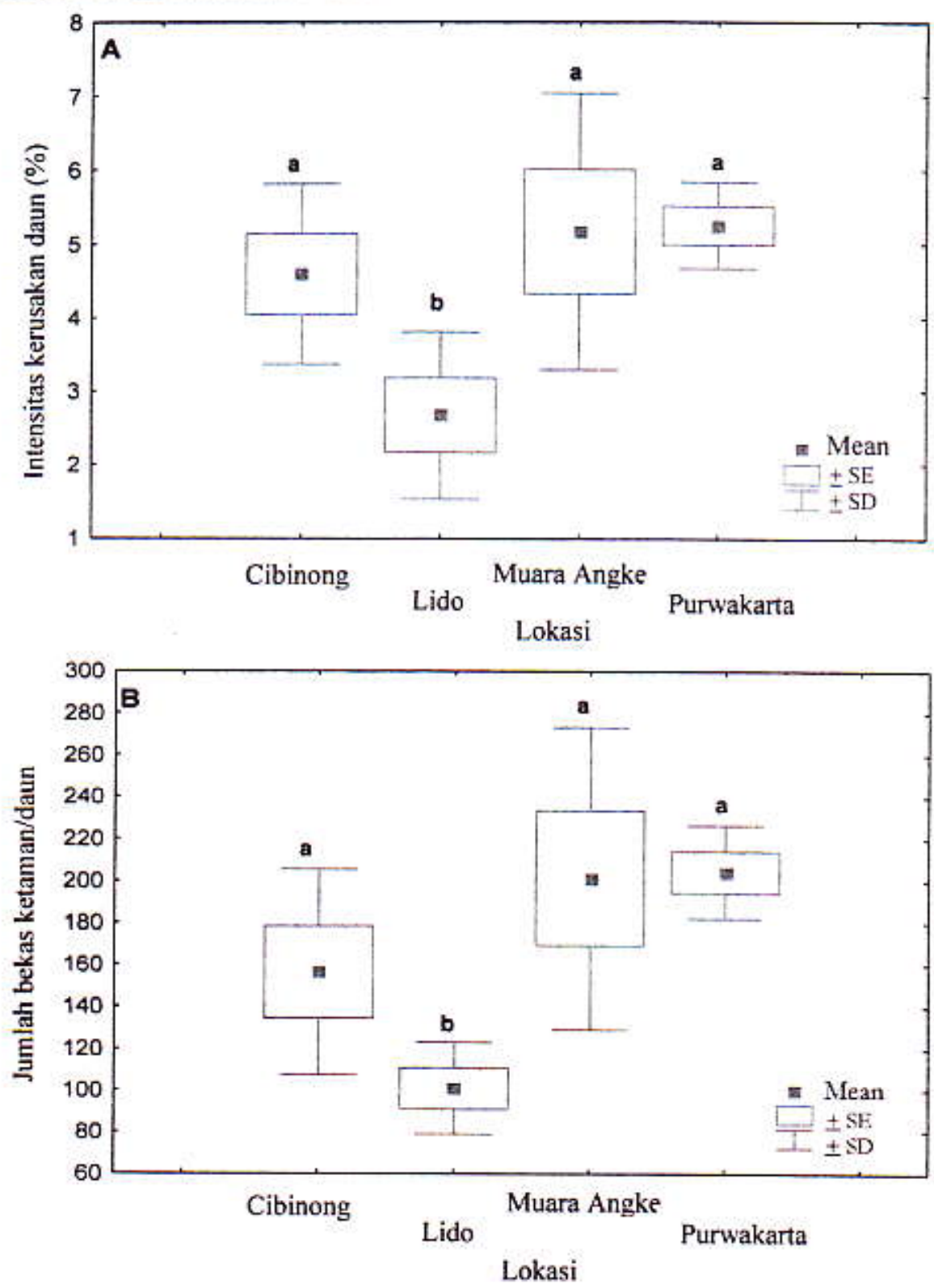

Gambar 1. Rata-rata intensitas kerusakan daun eceng gondok (A) dan jumlah bekas ketaman (B) yang disebabkan oleh $N$. eichhorniae 
Hasil pengamatan terhadap aktivitas makan $N$. eichhorniae mengindikasikan bahwa agens hayati ini sebenarnya cukup aktif. Hal ini ditunjukkan oleh adanya korelasi positif yang nyata antara jumlah bekas ketaman per helai daun dengan kelimpahan individu imago kumbang tersebut $(\mathrm{r}=0,756 ; \mathrm{p}<0,001)$ (Gambar 2).

\section{Implikasi $N$. eichhorniae terhadap Parameter Pertumbuhan Eceng Gondok}

Meskipun $N$. eichhorniae terlihat cukup aktif merusak, namun dari hasil pengamatan terungkap bahwa pengaruh keberadaan agens hayati ini tidak konsisten terhadap

\begin{abstract}
semua parameter pertumbuhan eceng gondok. Hasil analisis menunjukkan bahwa secara umum kelimpahan individu agens hayati tersebut tidak memiliki hubungan yang nyata dengan penurunan parameter pertumbuhan eceng gondok, yang meliputi biomassa (Gambar 3), jumlah daun per rumpun (Gambar 4), dan diameter daun (Gambar 5). Meskipun peningkatan kelimpahan individu $N$. eichhorniae cenderung mengakibatkan penurunan biomassa dan jumlah daun per rumpun eceng gondok, namun penurunan ini tidak nyata.
\end{abstract}

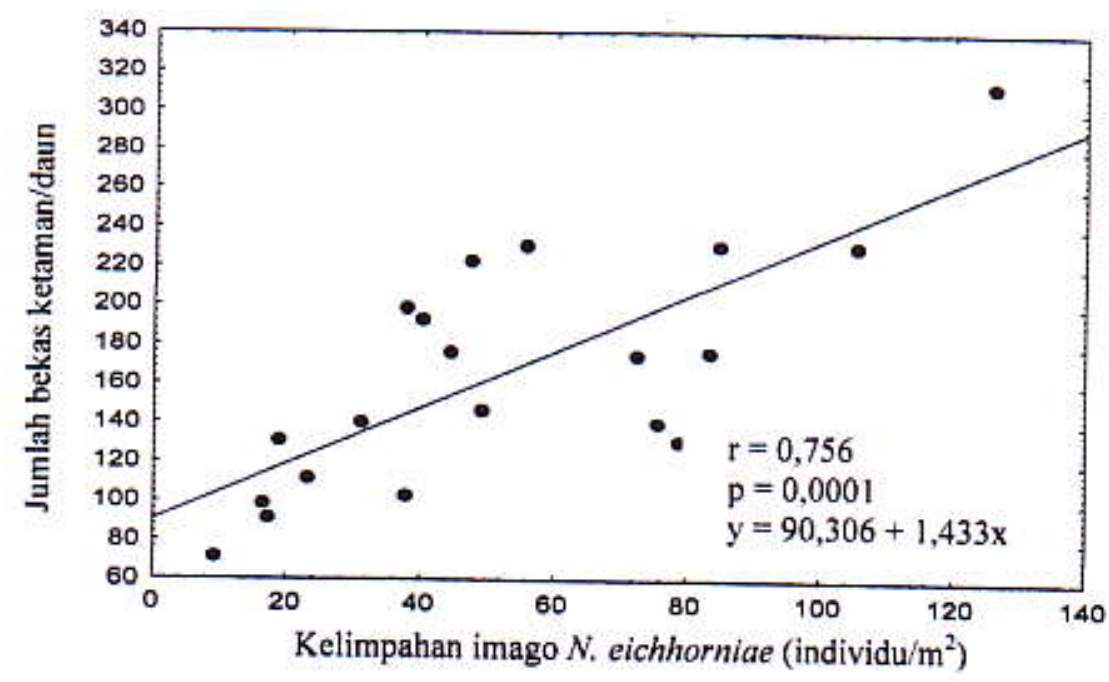

Gambar 2. Korelasi antara jumlah bekas ketaman dengan kelimpahan individu imago N. eichhorniae 


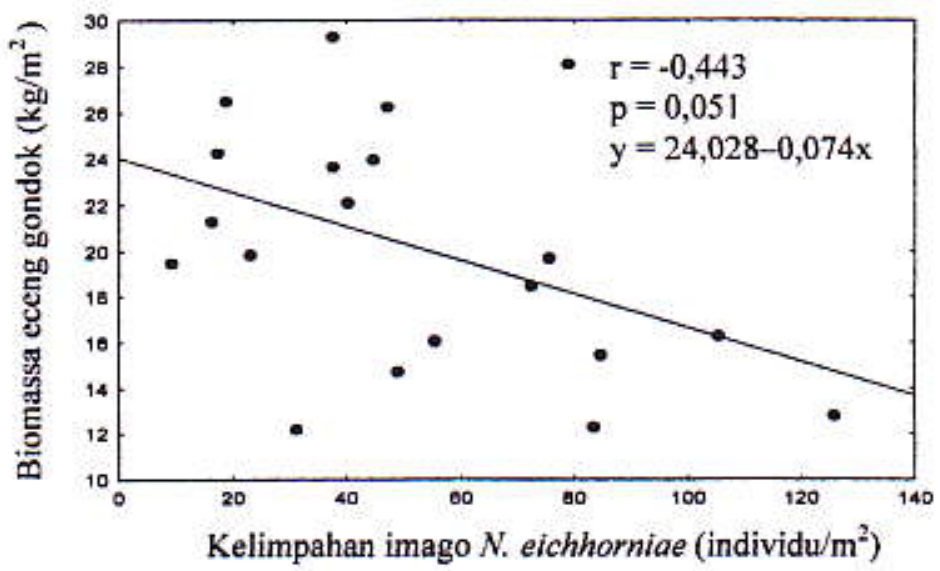

Gambar 3. Korelasi antara kelimpahan imago $N$. eichhorniae dengan biomassa eceng gondok

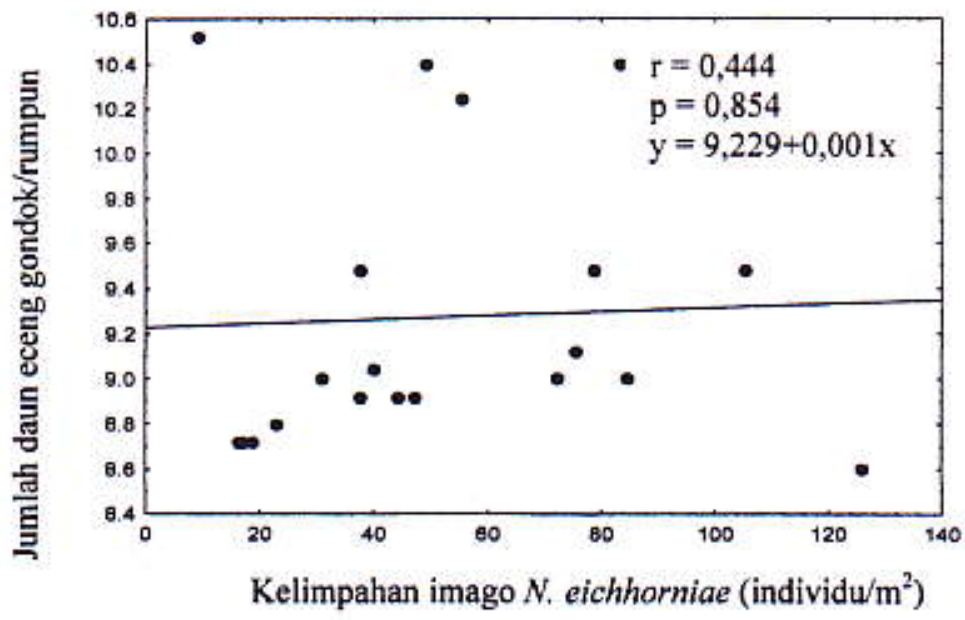

Gambar 4. Korelasi antara kelimpahan imago $N$. eichhorniae dengan jumlah daun eceng gondok

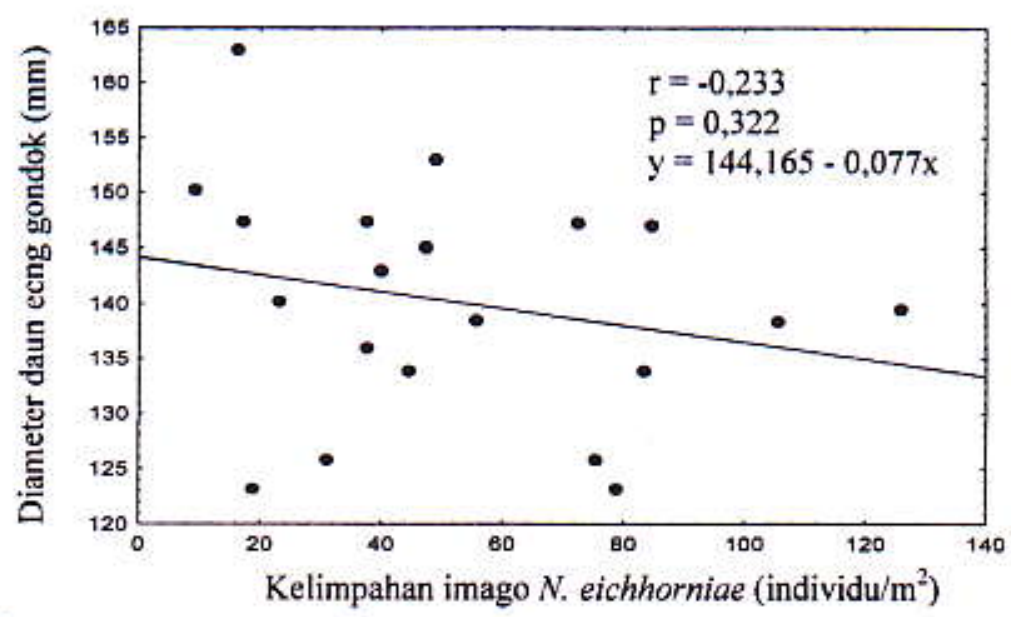

Gambar 5. Korelasi antara kelimpahan imago N. eichhorniae dengan diameter daun eceng gondok 


\section{Pembahasan}

Berdasarkan hasil pengamatan terhadap intensitas kerusakan daun dan jumlah bekas ketaman $N$. eichhorniae per helai daun eceng gondok terlihat bahwa populasi kumbang tersebut tidak mampu menimbulkan pengaruh yang nyata terhadap eceng gondok. Hal ini berkaitan erat dengan kelimpahan individu agens hayati ini yang sangat rendah (rata-rata kurang dari 3 individu per rumpun eceng gondok) sehingga tidak mampu menimbulkan kerusakan yang nyata pada gulma invasif tersebut. Dengan kata lain, agens hayati tersebut tidak dapat menyebabkan penurunan populasi eceng gondok secara nyata hinggga di bawah ambang pengendalian. Berbeda dengan fakta di Danau Victoria, Uganda, populasi yang tinggi (rata-rata 25 individu per rumpun eceng gondok) dapat mengakibatkan bagian eceng gondok di atas permukaan air mati dan tenggelam ke dasar danau (Ogwang, 2001).

Dua pasang imago $N$. eichhorniae membutuhkan waktu 1 bulan untuk mematikan 1 rumpun eceng gondok (Tjitrosemito 2002), padahal waktu yang dibutukan eceng gondok untuk menggandakan jumlah rumpunnya (doubling time) dilaporkan berkisar antara 9,2 hingga 32,2 hari (Gopal \& Sharma 1981). Selain itu, dari hasil pengamatan di lapangan terlihat bahwa $N$. eichhorniae tidak ditemukan pada semua rumpun eceng gondok. Dengan demikian, individu eceng gondok yang tidak terserang oleh kumbang tersebut akan berkembang dengan laju pertumbuhan normal. Kondisi ini mengakibatkan populasi agens hayati tersebut tidak mampu mengimbangi perkembangan populasi eceng gondok.

Keberadaan $N$. eichhorniae juga tidak mempengaruhi parameter pertumbuhan eceng gondok (biomassa, jumlah daun per rumpun, dan diameter daun). Memang ada kecenderungan bahwa peningkatan kelimpahan individu agens hayati tersebut akan mengakibatkan penurunan biomassa dan jumlah daun per rumpun eceng gondok, namun korelasinya sangat lemah. Hal ini mengindikasikan bahwa keberadaan agens hayati tersebut tidak akan mampu menghambat pertumbuhan eceng gondok, apalagi untuk menekan perkembangan populasi gulma invasif tersebut.

Menurut Forno dan Julien (2000), ada tiga metode yang digunakan untuk mengevaluasi potensi keberhasilan suatu agens pengendalian hayati gulma. Metode tersebut meliputi: 1) penilaian terhadap keberhasilan agens hayati secara biologi (mengukur kemampuan suatu agens hayati untuk menggunakan spesies gulma sasaran sebagai inang), 2) penilaian dampak agens hayati terhadap tanaman inang (mengukur penurunan reproduksi dan biomassa spesies gulma sasaran), dan 3) 
penilaian terhadap keberhasilan pengendalian (merefleksikan keuntungan ekonomi dan lingkungan bagi manusia akibat penurunan biomassa spesies gulma sasaran). Data yang diperoleh dari penelitian ini menunjukkan bahwa $N$. eichhorniae hanya dapat mencapai keberhasilan secara biologi.

Kemapanan $N$. eichhorniae di lapangan ternyata tidak serta-merta menjadi jaminan keefektifannya untuk menekan populasi eceng gondok. Hal ini sesuai dengan laporan Bellows (2001) bahwa agens hayati introduksi, yang mampu hidup dan bereproduksi di lingkungan baru, kemungkinan hanya memiliki dampak terbatas terhadap inang target. Lebih lanjut Confrancesco (2000) menyatakan bahwa keefektifan suatu agens pengendalian hayati gulma berkaitan dengan beberapa faktor atau kondisi, misalnya kepadatan populasi atau bagaimana agens hayati tersebut berinteraksi dengan tumbuhan target dan lingkungannya.

Bertitik tolak pada uraian di atas dapat dikemukakan bahwa dengan adanya kendala-kendala perkembangan populasi $N$. eichhorniae seperti musuh alami, baik berupa predator (Kasno et al. 2001; Widayanti et al. 1999) maupun patogen (Rebelo \& Center 2001), serta persentase imago betina yang rendah, telah mengakibatkan populasi kumbang tersebut di Indonesia dalam kurun waktu hampir 3 dekade setelah diintroduksi selalu saja rendah. Kelimpahan agens hayati tersebut diprediksi tidak pernah cukup tinggi untuk menekan perkembangan populasi eceng gondok. Sebaliknya agens hayati ini juga tidak akan punah selama eceng gondok masih ada. Hal ini didasarkan pada beberapa hasil penelitian yang sejauh ini menunjukkan bahwa $N$. eichhorniae hanya dapat menyelesaikan siklus hidupnya pada eceng gondok (Subagyo et al. 1977; Center 1994).

\section{KESIMPULAN}

Intensitas kerusakan eceng
gondok akibat keberadaan $N$. eichhorniae sangat rendah. Selain itu, parameter pertumbuhan eceng gondok juga tidak dipengaruhi oleh keberadaan agens hayati ini. Dengan demikian, keberadaan $N$. eichhorniae sejauh ini tidak dapat menekan perkembangan populasi eceng gondok. Monitoring terhadap populasi agens hayati ini perlu dilakukan secara periodik untuk mengetahui penyebab rendahnya populasinya.

\section{DAFTAR PUSTAKA}

Bellows TS. 2001. Restoring population balance through natural enemy introductions. Biological Control 21: 199-205.

Center TD. 1994. Biological control of weeds: waterhyacinth and waterlettuce. $\mathrm{Di}$ dalam: Rosen D, Bennet FD, Capinera $\mathrm{JL}$, editor. Pest management in the subtropics: Biological control-a Florida perspective. Intercept Ltd, Andover, UK. 
Center TD, Dray Jr FA, Jubinsky GP, Leslie AJ. 1999. Waterhyacinth weevills (Neochetina eichhorniae and N. bruchi) inhibit waterhyacinth (Eichhornia crassipes) colony development. Biol Cont 15: 39-50.

Center TD, Hill MP, Cordo H, Julien MH. 2002. Waterhyacinth. Dalam: Van Driesche $\mathrm{R}$ et al. Biological control of invasive plants in the Eastern United States. USDA Forest Service Publication FHTET,

Confrancesco AF. 2000. Factors to consider when using native biological control organisms to manage exotic plants. $J$ Aquat Plant Manage 38: 117-120.

Forno IW, Julien MH. 2000. Success in Biological Control of Aquatik Weed by Arthropods. Dalam Gurr, G. and Wratten, S. (Eds). Biological Control: Measures of Success. Kluwer Academic Publishers, London.

Gopal B, Sharma KP. 1981. Water-hyacinth (Eichhornia crassipes), the most troublesome weed of the world. Hindasia, New Delhi.

Kasno, Putri ASR. Widayanti S, Sunjaya. 2001. Establisment of Neochaetina sp.: Their pattern of local dispersal and age structure at release site. BIOTROPIA 13:18-29.

Ochiel GS, Njoka SW, Mailu AM, Gitonga W. 2001. Establishment, spread and impact of Neochetina spp. on water hyacinth in Lake Victoria, Kenya. Dalam: Julien, M.H., Hill, M.P., Center, T.D., and Jianqing, D. (Eds). Biological and integrated control of water hyacinth,
Eichhornia crassipes. P. 89-95. ACIAR Proceedings 102.

Ogwang J. 2001. Is there resurgence on Lake Victoria? Dalam IMPECCA. Biological and integrated control of Eichhornia crassipes. Water hyacinth news No, 4 . CABI Bioscience, Silwood Park, UK,

Rebelo MT, Center TD. (2001). Microsporidia \& Neochetina. Di dalam: IMPECCA. Biological and integrated control of Eichhornia crassipes. Water hyacinth news No. 4. CABI Bioscience, Silwood Park, UK.

Subagyo T, Kasno, Mangoendihardjo S. 1977. Masalah dan pengendalian tumbuhan pengganggu air Rawa Pening. Laporan Akhir 1976-1977. SEAMEO BIOTROP, Bogor.

Tjitrosemito S. 2002. Pengelolaan gulma air secara terpadu. Makalah, disampaikan pada kunjungan staf Perum Jasa Tirta, Malang ke SEAMEO BITROP, 17 Januari 2002.

Tjitrosoedirdjo SS, Widjaya F. 1991. Aquatic weed management in Indonesia. $\mathrm{Di}$ dalam: Proceedings of The Symposium on Weed Management. Bogor, 15-17 Mei 1990. BIOTROP Special Publication 40: 25-38.

Widayanti S, Kasno, Tjitrosoedirdjo SS, Tjitrosemito S. 1999. Efforts in using water hyacinth weevils to control water hyacinth in Indonesia. Dalam Proceedings of The Workshop on Integrated Weed Management in Managed and Natural Ecosystem. Bogor, 23-25 Juni 1998. BIOTROP Special Publication 61: 163-171. 